\title{
Mennonite Engagement with Iran
}

\author{
Ed Martin
}

\begin{abstract}
The Mennonites relationship ongoing with Iran has developed over a period of more than twenty years. This essay traces the development of our relationships with Iranians and our program with Iran, how it began with relief and reconstruction and progressed through a student exchange to an ongoing interfaith dialogue and visiting scholars. The roles of several key Iranians, to whom much credit must be given, will also be discussed. The views expressed herein concerning the development of Mennonite engagement with Iran are the personal views of the author and do not represent those of any Mennonite institution.
\end{abstract}

\section{Introduction: Relief and Reconstruction}

Mennonite involvement in Iran began after the disastrous earthquake in June 1990 in the northwestern provinces of Gilan and Zanjan. MCC wanted to respond for two reasons. One was the scale of the tragedy - more than 35,000 people had been killed and many more were injured and homeless. MCC does not respond to all major disasters, particularly if there is no history of involvement in the affected country. The second reason was the geo-political situation: the Cold War had just ended with the destruction of the Berlin Wall and the collapse of the Soviet Union. It seemed to some of us that, in Washington's eyes, political Islam had replaced communism as the enemy and that Tehran, instead of Moscow, was seen as the source of all evil in the world. We felt

Ed Martin writes from his experience as director of the Mennonite Central Committee's (MCC) Central and Southern Asia program and as director of Eastern Mennonite University's (EMU) Center for Interfaith Engagement (CIE). MCC, the relief, development, and peacebuilding organization of the Mennonite churches of the United States and Canada, is active in about sixty countries. He served with MCC from August 1989 to October 2007, during which the program with Iran was initiated and developed. Since October 2010, he has been director of CIE. 
that our organization should respond to demonstrate that it would help ease human need in any country, irrespective of its religion and politics. MCC wanted to reach out to the people of Iran in order to build bridges of understanding and friendship.

Prior to this earthquake, MCC had no program or contacts in Iran and there were no diplomatic relations between the United States and Iran. Unsure of how to proceed, we contacted Church World Service, Catholic Relief Services, and the World Council of Churches. But their advice - to contribute to the US Red Cross and that the funds or material resources would eventually reach Iran - could not enable us to initiate a more direct relationship with Iran. In the meantime, the MCC office in Ottawa (Canada) contacted the Iranian embassy in Ottawa and informed them of the Mennonites' desire. The embassy introduced us to a Toronto Islamic center that was collecting funds and material resources. Through this connection, we sent a shipment of medical supplies to the Iranian Red Crescent Society (IRCS); Iran Air provided free air freight.

MCC then sent a letter to the Iranian embassy saying that it would also like to contribute to the reconstruction effort and asking if it could send a delegation to Iran to explore how it could best do this. Some MCCers were skeptical that such permission would be given. Then in August 1990, when Iraq invaded Kuwait and Washington began a large military buildup in the region, it seemed extremely unlikely that such permission would be forthcoming. Much to our surprise, however, later that fall the Ottawa office reported that permission had been given, that the delegation could include both Canadians and Americans, and to inform it when the delegation would like to visit.

The resulting four-man delegation - two Canadians and two American citizens - visited Iran during January 5-14, 1991, immediately before the start of the first Persian Gulf War. The members was hosted by the Ministry of Foreign Affairs and the IRCS. After a visit to the earthquake-affected area and discussions with the IRCS and government agencies, MCC decided to fund the construction of fifteen village health clinics ("health houses") to be built by the Housing Foundation, the government agency responsible for reconstruction.

During this visit, we made our first important contact: Sadreddin Sadr (director general for international affairs, IRCS), who had a vision of what cooperation between MCC, a North American Christian humanitarian organization, and the IRCS, an Iranian essentially Islamic humanitarian organization, would symbolize. The IRCS is a very large, extremely capable, and experienced relief organization that did not need MCC's modest contributions; in fact, it valued the cooperative relationship. Sadr asked MCC personnel to speak to his staff about our organization and the values motivating its humanitarian service. 
MCC cooperated with the IRCS' response to several natural disasters earthquakes, floods, drought - as well as Iraqi refugee relief following the first Persian Gulf war. It also assisted with Afghan refugees by providing funding for the IRCS, which is noted for its experience and expertise in orthopedic rehabilitation, to treat Afghans injured during the war in Afghanistan. MCC also provided resources to assist internally displaced Afghans in IRCS-run camps inside Afghanistan during the United States' 2002 war with the Taliban.

The IRCS was the MCC's Iran program primary partner for the first six years of this engagement. For example, it would arrange visa authorizations and host MCC officials. Through this partnership, staff members were able to travel to many areas of Iran to see the IRCS' work and meet many of its very capable and dedicated staff. After one visit, which included John Lapp (executive director, MCC), MCC decided to make a five-year commitment of regular funding to IRCS in addition to offering special assistance at times of major disasters.

\section{The Student Exchange Program}

In 1993 Sadreddin Sadr's wife, a sociology professor, received a fellowship to spend a year at the Center for Muslim Christian Understanding at Georgetown University in Washington, DC. Mr. Sadr took a leave of absence from the IRCS to accompany his famly in Washington, and MCC arranged for him to be a partner in residence in its Washington office. For the next five months, he helped interpret events in the Middle East, was involved in other efforts, and came to know the staff very well. He also visited MCC headquarters in Akron (PA) to speak to staff and to address the executive committee of the board of directors. Such interaction enabled him to become better acquainted with the Mennonites.

During his visit to the Iranian Mission to the United Nations, Sadr explained to the ambassador and some of the staff the relationship that was developing between our two groups. Following that visit, he encouraged MCC to visit the Iranian Mission. MCC program staff took him up on this offer and introduced our organization to Ambassador Kamal Kharrazzi and some of his staff, which led to a second key relationship: Seyed Kazem Sajjadpour, a senior official of the Iranian Mission and a representative of the Institute of Political and International Studies (IPIS), the research and policy-making department of the Iranian Ministry of Foreign Affairs.

MCC usually does not simply give grants to partners; it also sends personnel to live in those countries in which it is involved. We very much wanted 
to have MCC volunteers living in Iran in order to develop ties of understanding and friendship between Americans and Iranians. However, the normal MCC approach of sending service workers and setting up an office to engage in relief and development work seemed impossible. During the Cold War, MCC sent graduate students to universities in East Berlin, Prague, Warsaw, Belgrade, and elsewhere to get to know Eastern European peoples and cultures. Based on this experience, we thought of proposing a similar program. But MCC wanted to do more than just send students; we wanted to host Iranian students in Mennonite communities while they studied in North American universities.

Both Ambassador Kharrazzi and Seyed Sajjadpour were interested in this idea and encouraged MCC to send a proposal that they would take with them to Iran. MCC wanted the students it sent to study Farsi, Islam, Persian literature, and Iranian history, and expected that Iran would likely want to send engineering and science students. We were pleasantly surprised when informed that Iran wanted to send some of its top philosophy and theology students to study the philosophy of religion.

In April 1997, MCC Executive Director Ron Mathies and Central and Southern Asia Program Director Ed Martin went to Iran and negotiated a student exchange agreement with Qom's Imam Khomeini Education and Research Institute (IKERI). IKERI initially proposed that their students study at Montreal's McGill University, as some of their faculty had studied there. MCC proposed the University of Waterloo because of the area's sizeable Mennonite community. A compromise - Toronto - was accepted and has worked out well: MCC students study Farsi and Islam at IKERI and Iranian students study the philosophy of religion at the Toronto School of Theology. Despite its extremely conservative political and religious orientation, IKERI was willing to host Mennonite Christians and to send some of its best students to study in Canada.

When this exchange program was presented to the MCC board, some members worried that the MCCers would water down their Christian faith when engaging in dialogue. Program Administrator Martin assured them that this would not be the case, for sincere interfaith dialogue requires participants to present their faith both clearly and fully. In fact, one IKERI professor told an MCC student couple that they should go home if they ever sensed a desire to convert to Islam, for he wanted only strong Christians who could engage in serious dialogue from a Christian perspective

Since the IKERI-MCC exchange agreement was signed in 1997, four Mennonite couples have studied in Qom and the fathers of two Iranian families studying in Toronto have completed Ph.D. degrees in the philosophy of religion. Both groups of students had opportunities to speak in various settings 
about their faith and their country, which helped them get to know each other as neighbors and study each other's religion, an important aspect each participant's life.

\section{Interfaith Dialogue Conferences}

A series of interfaith dialogue conferences has grown out of the relationships developed via the student exchange program. There have been five interfaith conferences in all - three in Canada and two in Qom - initiated by Jim Reimer (director, the Toronto Mennonite Theological Center; the host institution for the Iranian students studying in Toronto) and Aboulhassan Haghani (IKERI). The purpose behind these undertakings is to build on the existing relationships and to enable the participating scholars to know each other better and to engage in dialogue on issues of common interest. According to Reimer, "The purpose of these dialogues is to promote mutual understanding and mutual conversion. I don't mean conversion of Muslims to Christianity, let alone Anabaptism, or Christians to the Islamic faith, but rather through a mutual encounter to convert one another to a deeper understanding and commitment to one's own faith, to aspects of one's tradition that have perhaps been overlooked."'1

The topics of the conferences have been as follows:

- The Challenge of Modernity: Shi'ah Muslim-Mennonite Christian Dialogue. This conference, held in Toronto in October 2002, examined the issues of modernity and compared how Shi'ah Muslims and Mennonite Christians have responded to its challenges. Included were discussions of how modernity has affected the view of faith and reason. In the West modernity has brought about a separation of faith and reason, of religion and science, in a way that is foreign to Muslim thinking. The Muslim stance was seen as ambiguous: neither total rejection nor full acceptance. While saying "no" to modern secularism and the rejection of God, as well as to the accompanying moral decadence, they say "yes" to modern science, reason, and technology. ${ }^{2}$

- Revelation And Authority: Shi'ah Muslim-Mennonite Christian Dialogue II. Qom, home of most of Iran's Shi' ah seminaries, hosted the second conference in February 2004. Themes in the formal presentations included revelation, reason, authority, law, conscience, canonical texts, religious experience, and Islamic and Christian views of God. The dominant motif was the relation of revelation to reason. The discussion showed Muslims 
as possessing a high view of human reason (a gift from God) as well as of revelation (the divine will as revealed through Gabriel to Prophet Mohammad in the Qu'ran). Unlike Christianity's doctrine of Original Sin, which has corrupted human nature (including reason), Islam has a more positive anthropology: human beings are naturally oriented toward the divine. While people do have a tendency to sin, Islam does not consider this an inherited condition. Moreover, God expects them to use their reason fully in determining right from wrong and to follow a path of obedience. In their high view of reason, freedom, and human responsibility, in addition to their rejection of the more severe Protestant notions of Original Sin, Mennonite Christians have something in common with Shi'ah Muslims. ${ }^{3}$

- On Spirituality: Shi'ah Muslim-Mennonite Christian Dialogue III. The third dialogue was hosted by Ontario's Conrad Grebel University College, a college of the University of Waterloo, during May 2007. The first (and only public) session was shut down by expatriate Iranian demonstrators protesting any dialogue with Iranian scholars from IKERI.

Mennonite scholars had proposed the theme, and their Iranian counterparts had accepted it. The conference showed that while spirituality is important for both communities, each has a somewhat different understanding of its nature. "For Anabaptist-Mennonites, spirituality is closely linked to the doctrine of the Holy Spirit, the source of a regenerated life of Christian discipleship, including nonviolent love in human relations. Spirituality is largely experiential. Shi'ah Muslims, while not rejecting the experiential nature of spirituality altogether, tend towards a more philosophical, mystical, and ritual form of spirituality. Spirituality, rationality, and the political life of the community are not as strictly separated as they are in many forms of Christianity."

- Peace and Justice: Shi'ah Muslim-Mennonite Christian Dialogue IV. IKERI hosted the fourth dialogue in Qom during May 2009. The fourteen presentations clustered around three topics. The first was peace, war, and protection. While both groups have somewhat divergent views on peace and war, Muslims also argue that war is wrong and Mennonites find ways to reassess the justice implications of pacifism. Also addressed were the topics of just war and the philosophical meaning of peace. A second set of papers focused on how the Qur'an and the Bible inform their adherents' views of peace and justice. Special attention was given to how these scriptures contribute to our understandings of peace and justice. The third set explored several important themes that have become significant to both 
faith traditions. All religions develop traditions, and these traditions express practices and customs that give content to the faith. Peace and justice are expressed in social realities, in concrete practices that have shaped both communities' theological identities. Notions such as ecclesiology, eschatology, martyrdom, jihad, political theology, and peacemaking practices become vehicles through which peace and justice become meaningful. This group of papers gave attention to some of these subthemes. ${ }^{5}$

- On Being Human: Shi'ah Muslim-Mennonite Christian Dialogue V. The papers and discussion focused on the theological understanding of human nature, both the commonalities and differences. Presenters examined how the scriptures of the two faiths inform our understanding of human nature, the concept of human perfection, and the relationship of faith and culture. Human rights and human rights language was another topic for dialogue. ${ }^{6}$

A sixth conference is scheduled for the end of May 2014, in Qom. The topic will be ethics.

Some of the same people have participated in nearly all of the conferences, and the level of dialogue and sharing has increased throughout the series of dialogues. M. Darrol Bryant (University of Waterloo), an expert in interfaith dialogue, attended the third conference as an observer. He remarked afterward that it was the best one he had ever attended, citing the depth of dialogue and friendship between the participating scholars, which he attributed to the longstanding relationship between them. Also there were Mennonite participants who had lived in Qom and students from Qom who had lived in Ontario, and all of them had made particularly good friends with people of the other faith.

It should be mentioned that there has been strong criticism directed toward the Mennonites for engaging in dialogue with conservative Iranian Muslims. However, the Mennonite position has always been that it is important to dialogue with anyone, including those with whom one may not agree. And at a time where Tehran and Washington have no diplomatic relations and very little contact, it is important to engage Iranians. ${ }^{7}$

\section{Additional Exchanges}

IKERI and other institutions in Iran have hosted three learning tours of Canadian and American Mennonites. Such an opportunity to meet ordinary Iranians and experience their generous hospitality, attend lectures on Islam and Iran, see historical sites, and observe the rich Iranian culture is very rare for North Americans. 
Through our contacts in Iran, three Mennonite professors were invited to a conference in Iran on Mahdism in 2006. In 2007, Mennonites and Quakers led a delegation to Iran that was co-hosted by the Center for Interreligious Dialogue and the Ministry of Foreign Affairs. A delegation of Mennonite university professors and administrators visited Iran in 2008 to explore exchange possibilities with several universities and institutions. Mennonites have also facilitated the visits of Iranian scholars to American academic institutions.

The Center for Interfaith Engagement at Eastern Mennonite University has hosted a couple of visiting Iranian Islamic scholars for the past eighteen months. They are teaching "Introduction to Islam," "Issues in Islam," "Islamic Spirituality," "Women in Islam," "Elementary Farsi," "Women, Religion, and Politics in Iran," and other courses. They are also wonderful resources on Islam and Iran both on campus and in the local community.

The center and the university believe it is very important for students at a Christian liberal arts university to learn about other faiths from practitioners of those faiths and to become comfortable with them, particularly Muslims. Due to the growing Muslim population in the United States, Americans will encounter Muslims in their professional and social lives. It is important that they feel comfortable when relating to them and do so with an attitude of respect.

EMU's Center for Justice and Peacebuilding has hosted at least ten Iranian participants in its six-week Summer Peacebuilding Institute, during which peace practitioners and scholars from many countries spend six weeks in classes and intense interaction. Two Iranian participants returned to complete EMU's master degree program in conflict transformation and peacebuilding.

I am hopeful that more exchanges will be possible in the future, for it seems that American and Iranian diplomats are finally beginning to meet for serious negotiations over Iran's nuclear program and other issues. When Iran's new president, Hassan Rohani, addressed the UN General Assembly on September 24, 2013, he stated that exchanges between the people of the two countries are very important. It is my hope that both governments will make it easier for students and academics to obtain visas to engage in such activities. Now the visa process for citizens of both countries is very cumbersome, timeconsuming, and expensive.

\section{Keys to Authentic Engagement}

- Transparency. From the very first visit to Iran, Mennonites made it clear that they represented a church-related agency whose humanitarian service was motivated by their religious faith and the teachings of Jesus. 
MCC personnel had to be ready to discuss their faith in many different settings with ambassadors, foreign ministry officials, and religious leaders and scholars.

- Respect. It is very important to treat people with respect, to adjust schedules and menus according to their needs.

- Patience and Persistence. Developing a program and long-term relationships across the political and religious divides evident between the United States and Iran requires great patience and persistence. Developing relationships of trust takes time and multiple encounters. On a practical matter, visas were often approved only at the last minute, and many people would have abandoned the effort. Mennonites worked closely with the hosting agency and the foreign ministry to secure visas. Several times travel had to be rerouted to collect a passport from the embassy in Ottawa or the Interests Section in Washington, because there was not enough time for it to be mailed to the traveler.

- Openness to the leading of the Spirit (Vision). The Mennonites' involvement in Iran did not develop in response to a well-developed, long-term strategic plan, but with a vision - to promote relationships between Iranians and North Americans - and then responded to the opportunities that arose.

\section{Endnotes}

1. A. James Reimer, "Revelation and Authority: Shi'ah Muslim-Mennonite Christian Dialogue II," The Conrad Grebel Review 24, no. 1 (winter 2006).

2. A. James Reimer, "The Challenge of Modernity: Shi'ah Muslim-Mennonite Christian Dialogue," The Conrad Grebel Review 21, no. 3 (fall 2003).

3. Reimer, "Revelation and Authority."

4. M. Darrol Bryant, Susan Kennel Harrison, and A. James Reimer, eds., On Spirituality: Essays from the third Shi'i Muslim Mennonite Christian Dialogue Kitchener, Canada: Pandora Press 2010).

5. Harry J. Huebner and Hajj Muhammad Legenhausen, eds., Peace and Justice: Essays from the Fourth Shi'i Muslim Mennonite Christian Dialogue Winnipeg, Canada: CMU Press, 2011).

6. Harry J. Huebner and Hajj Muhammad Legenhausen, eds., On Being Human: Essays from the Fifth Shi'i Muslim Mennonite Christian Dialogue (Winnipeg, Canada: CMU Press, 2012).

7. Mahdi Tourage, "Fetishizing Dialogue and Commodifying Peacemaking," American Journal of Islamic Social Sciences 26, no. 1 (winter 2009). 